\title{
Religious Community Responses to the Public Policy of the Indonesian Government Related to the Covid-19 Pandemic
}

\author{
Amos Sukamto \\ Senior lecturer and researcher in the history of Christianity and \\ Muslims-Christians relations in Indonesia at INTI Theological \\ Seminary, Bandung, West Java, Indonesia \\ amossukamto@gmail.com
}

\section{S. Panca Parulian}

Lecturer and researcher in biblical and contextual theology at INTI Theological Seminary, Bandung, West Java, Indonesia limapanca888@gmail.com

\begin{abstract}
The purpose of this article is to analyze religious responses to the policy of Indonesian government in dealing with the covid-19 pandemic. Article 4 of Government Regulation (PP) No. 21/2020 mentions restrictions on religious activities. The response of the religious community to this government policy was varied. The Council of Indonesian Ulama, Majelis Ulama Indonesia (MUI), issued several fatwas containing a ban on worship involving large numbers of people. A small group of fanatic Muslims initially opposed the policy, but eventually followed it. Among Protestants, the mainstream and Pentecostal churches under the Communion of Churches in Indonesia (PGI) are highly coordinated with government regulations. Some Pentecostal churches attempted to continue holding worship together for reasons of holy communion, but eventually they followed government regulations. The Catholic church followed government regulations consistently.
\end{abstract}

\section{Keywords}

COVID-19 - Indonesian government policy - Islam - Protestantism - Catholicism 
The Covid-19 pandemic, which started in Wuhan, China, at the end of December 2019 and quickly spread, forced the Chinese government to quarantine Wuhan on January 23, 2020. On January 30, 2020, the World Health Organization (WHO) declared it "a global public health emergency."1 COVID-19 spread rapidly to the Philippines, South Korea, Iran, Italy, Spain, Singapore, Malaysia, and Indonesia. On April 22, 2020, the вв С News reported that " $t]$ here are now more than 2.6 million confirmed cases of coronavirus in 185 countries as the disease continues to spread. At least 181,00o people have died." ${ }^{2}$ The rapid spread of COVID-19 has transformed the social order of mankind, including the lives of individuals who lead a religious life.

The present article explores three issues: (a) the policy of the Indonesian government in response to the spread of COVID-19 in Indonesia; (b) the way in which this policy affected the lives of the religious community in Indonesia; and (c) the way in which the religious community in Indonesia responded to the public policy of the Indonesian government regarding the CoviD-19 epidemic.

\section{Indonesian Government Policy in Response to COVID-19}

The first case of CoviD-19 infection in Indonesia was detected by the government on March 2, 2020, about two months after the virus was detected in Wuhan, China. ${ }^{3}$ Since the first case was announced, the number of positive cases of COVID-19 in Indonesia continued to grow, until May 15, 2020, the number of positive cases for CoviD-19 reached 16,496. ${ }^{4}$

How did the Indonesian government authorities respond to the CoviD-19 epidemic, especially with regard to religious life? Initially, the government issued only an appeal. On March 15, 2020, President Joko Widodo appealed to the people of Indonesia: "Under these conditions, it is time for us to work from home, learn from home, worship from home. This is the time to work together,

1 Holly Secon, Aylin Woodward, and Dave Mosher, "A Comprehensive Timeline of the New Coronavirus Pandemic, from China's First Covid-19 Case to the Present," Business Insider Singapore, 2020, https://www.businessinsider.sg/coronavirus-pandemic-timeline-history -major-events-2020-3? $r=U S \& I R=T$.

2 The Visual and Data Journalism Team, "Coronavirus Pandemic: Tracking the Global Outbreak - BвC News,” accessed April 23, 2020, https://www.bbc.com/news/amp/world-51235105.

3 Sarah Ervina Dara Siyahailatua, "Wabah Corona, Big Bad Wolf Hadir Secara Online Gaya Tempo.Co," Tempo.Co (Jakarta, April 2020), https://gaya.tempo.co/read/1334469/wabah -corona-big-bad-wolf-hadir-secara-online.

$4 \mathrm{Tim} / \mathrm{Kid}$, "Update Corona 15 Mei: 16.496 Positif, 3.803 Orang Sembuh," cNN Indonesia, May 15, 2020, https://www.cnnindonesia.com/nasional/20200515094631-20-503634/update-corona -15-mei-16496-positif-3803-orang-sembuh. 
to help each other, and be cooperative. We want this to be a community movement so that the problem is quickly resolved." Three important messages are conveyed in this appeal: to work, study, and worship at home.

Because religion is a highly sensitive issue in Indonesia, the government initially did not outright prohibit religious worship. The President merely appealed to the population, and worked through the Ministry of Religion, the Council of Indonesian Ulama (MUI), and several Protestant, Catholic, Hindu, Buddhist, and Kong $\mathrm{Hu} \mathrm{Cu}$ religious leaders to persuade Indonesian people to abide by the protocol for preventing the spread of CoviD-19, especially with physical distancing.

The appeal to worship at home affected greatly the lives of religious people in Indonesia. Muslims could not attend Friday prayers together, and entering the month of Ramadan, they could not conduct the Tarawih prayer together. Protestants and Catholics could not attend Sunday services and mass inside the church buildings, nor Easter mass and services. Yet no legal sanctions were imposed at this stage.

Between March and April 2020, President Joko Widodo has issued several legal decrees related to handling the spread of CovID-19, one of which concerned limitation of religious activities. On March 31, 2020, Government Regulation No. 21/2020 Concerning Large-Scale Social Distancing Restrictions to Accelerate Handling Covid-19 was issued. One article of this Regulation restricts religious activities:

\section{Article 4}

1. Large-scale social restrictions include at least:

a. Closing of schools and workplaces;

b. Restrictions on religious activities; and/or

c. Restrictions on activities in public places or public facilities.

2. Restrictions on activities as referred to in section (1) paragraph a and paragraph $b$ must continue to consider the educational needs, work productivity, and worship activity of the population.

3. The restriction on activities, as referred to in section (1) paragraph $\mathrm{c}$, is carried out by taking into account the fulfillment of the basic needs of the population. ${ }^{6}$

5 Syailendra Persada, "Jokowi Soal Corona: Saatnya Kita Kerja, Belajar, Ibadah Di Rumah," Tempo Co, March 15, 2020, https://nasional.tempo.co/read/1319821/jokowi-soal-corona-saatnya -kita-kerja-belajar-ibadah-di-rumah.

6 Presiden Republik Indonesia, "Peraturan Pemerintah Nomor 21 Tahun 2020 Tentang Pembatasan Sosial Berskala Besar Dalam Rangka Percepatan Penanganan Coronavirus Disease 2019/COVID-19" (2020). 


\section{Religious Community Responses to the Public Policies of the Indonesian Government Regarding the Covid-19 Pandemic}

Religious communities in Indonesia responded in different ways to the appeal of President Joko Widodo, issued on March 15, 2020, to Indonesian people to work, study, and worship from home. At first, some members of the religious communities, especially those who tended toward extremism in their religion, were opposed to worshiping from home, but opposition subsided quickly. Even religious organizations, such as the MUI and the National Council of Churches in Indonesia $\left(\mathrm{PGI}^{7}\right)$, were cooperating with the government appeal. Below I discuss the response of three of the main religions in IndonesiaIslam, Protestantism, and Catholicism — to the government appeal.

\subsection{Muslim Responses}

In Islamic law, Friday prayer is obligatory and must be performed by every healthy male Muslim (Surah Al-Jumu'ah: 9). ${ }^{8}$ Friday prayer must be attended by more than 40 people, therefore it does not conform to the rules of physical distancing. On the day following President Joko Widodo's appeal, on March 16, 2020, the MUI issued a fatwa \#14 on Organizing Worship under the Conditions of the COVID-19 Outbreak. ${ }^{9}$ The contents of the fatwa are as follows: (a) Friday prayers can be replaced with the Zuhr prayer for those who have been exposed to the coronavirus and in areas with high contagion potential; but (b) for those in areas with low transmission potential are still required to perform the religious prayer according to Islamic law, at the same time complying with the provisions of the health protocols. ${ }^{10}$

How did Muslims respond to the government appeal and the MUI fatwa? On March 19, 2020, Jakarta Governor, Anies Baswedan, requested the residents of Jakarta to abolish the Friday prayer and replace it with the Zuhr prayer in their respective locations, in accordance with the MUI fatwa. ${ }^{11}$ The appeal was conveyed to every mosque under his authority, but on Thursday, March 19, 2020, the administrators of the Istiqlal Mosque delivered a different announcement, stating that the imam of the Istiqlal Mosque would hold the Friday

\footnotetext{
7 Persekutuan Gereja-gereja di Indonesia.

8 Ahmad Sarwat, Ahmad Sarwat Seri Fiqih Kehidupan : 3 Shalat (Jakarta: DU Publishing, 2011), 227 .

9 “Fatwa Tentang Penyelenggaraan Ibadah Dalam Situasi Terjadi Wabah covid-19," Pub. L. No. 14, 1 (2020).

$10 \quad$ Ibid.

11 Taufiq Siddiq, "Istiqlal Gelar Jumatan Besok, Anies Sebut Fatwa MuI Soal Corona," Tempo Co, March 19, 2020, https://metro.tempo.co/read/1321667/istiqlal-gelar-jumatan -besok-anies-sebut-fatwa-mui-soal-corona.
} 
prayers on March 20, 2020, despite the Governor's request. ${ }^{12}$ This decision was later altered, and on March 20, 2020, the Friday prayer at the Istiqlal Mosque was canceled. ${ }^{13}$

The Masjid Raya Welfare Council (DKM ${ }^{14}$ ) in Bandung, West Java, responded to the circular letter ${ }^{15}$ of the Governor of West Java and of the Mayor of Bandung, issued on March 16, 2020, by installing billboards announcing the cancellation of Friday prayers. In response, several dozen residents tore down the billboards installed by Masjid Raya Bandung. ${ }^{16}$ On March 21, 2020, three representatives of the same group apologized for removing the billboards. ${ }^{17}$ Apart from Bandung, there was almost no direct opposition to the MUI fatwa, although on that date several mosques still held public Friday prayers, including the Jami 'Ar-Rahmah mosque located in the East Tebet sub-district in Tebet, South Jakarta, and the Great Al Azhom mosque in Tangerang, Banten. ${ }^{18}$ On the following Friday, however, many mosques no longer held public Friday prayers. ${ }^{19}$

Two weeks later it became apparent that the CoviD-19 pandemic was not receding but on the contrary, was intensifying. Friday prayers were cancelled twice in a row, despite a hadith according to which "He who misses Friday prayer (consecutively) for three Fridays on account of slackness, Allah will imprint a stamp on his heart," (Sahih At-Tirmudzi, At-Thabarani, Al-Daruqutni). ${ }^{20}$

\section{Ibid.}

13 Eno Dimedjo, "Ikut Saran MUI, Masjid Istiqlal Tiadakan Salat Jumat | Tagar," Tagar. Id, March 20, 2020, https://www.tagar.id/ikut-saran-mui-masjid-istiqlal-tiadakan-salat -jumat.

14 Dewan Kemakmuran Masjid.

15 Gubernur Jawa Barat No. 400/25/UM tanggal 13 Maret dan surat edaran walikota Bandung nomor: 443/SE.0.30-DINKES tertanggal 14 Maret 2020 yang isinya penutupan fasilitas umum dan penghentian sementara kegiatan yang melibatkan masa pada 16 Maret 2020) Bandung raya.

16 Muhammad Fauzi Ridwan, "Baliho Penutupan Jumatan Masjid Raya Bandung Dicopot Paksa | Republika Online," Republika, March 20, 2020, https://republika.co.id/berita/q7hv7j327/baliho-penutupan-jumatan-masjid-raya-bandung-dicopot-paksa.

17 Yudha Maulana, "Massa Yang Copot Paksa Spanduk Di Masjid Raya Bandung Minta Maaf," DetikNews, March, https://news.detik.com/berita-jawa-barat/d-4948222/massa -yang-copot-paksa-spanduk-di-masjid-raya-bandung-minta-maaf.

18 Mfp, "Covid-19: Mosques Defy Ulema Council Appeal to Suspend Friday Prayer," TheJakartaPost, March 21, 2020, https://www.thejakartapost.com/news/2020/o3/21/covid-19 -mosques-defy-ulema-council-appeal-to-suspend-friday-prayer.html.

19 Fuji E. Permana, "Umat Islam Diharap Taati Fatwa Ulama | Republika Online," Republika. Co.Id, March 25, 2020, https://republika.co.id/berita/q7qr47430/umat-islam-diharap-taati -fatwa-ulama.

$20 \quad$ Alhafiz Kurniawan, "Ini Hadits Rasulullah Seputar Meninggalkan Shalat Jumat Tiga Kali," NUonline, 2020, https://islam.nu.or.id/post/read/118620/ini-hadits-rasulullah-seputar -meninggalkan-shalat-jumat-tiga-kali. 
As reported by Kompas News, Sabhani ${ }^{21}$ hesitated to skip Friday prayers for the third time. ${ }^{22}$ The Secretary of MUI fatwa commission tried to persuade the Indonesian Muslim community that the context of the hadith was different from the current conditions. The hadith applies if someone who faces no obstacles or uzur (senility) deliberately shirks the obligation to attend the Friday prayer. The current situation of the CoviD-19 pandemic was considered to be equivalent to uzur (senility) or to an obstruction, which, according to Islamic law, allows people not to perform the obligation of worship. ${ }^{23}$

Medical workers who handled CoviD-19 patients were required to use personal protective equipment (PPE). The Muslims among them had difficulty performing shalat. ${ }^{24}$ Therefore, on March 23, 2020, Vice President, Ma'ruf Amin, urged the MUI to immediately issue a fatwa giving permission to someone in an emergency not to perform $w u d h u^{25}$ when performing shalat. ${ }^{26} \mathrm{On}$ March 26, 2020, the MUI issued fatwa \#17 of 2020 concerning the Prayer Guidelines for Medical Workers who Wear PPE when Caring for and Handling Patients with CoviD-19. The fatwa included several provisions on shalat for medical workers who handle covid-19 patients: (a) they were still obliged to perform shalat under various conditions, according to their ability; (b) they were permitted to perform shalatjamak (carry out two prayers at one time);(c) the were permitted to perform shalat using PPE; (d) they could replace wudhu with tayammum (ablution without using water); and (e) they were permitted to perform shalat without wudhu in an extreme situation. ${ }^{27}$

\footnotetext{
21 One of Jakarta resident.

22 Aditya Diveranta, "MUI Jelaskan Tentang Tiga Kali Tidak Shalat Jumat Saat Pandemi Kompas. Id," Kompas, April 3, 2020, https://kompas.id/baca/humaniora/ilmu-pengeta huan-teknologi/2020/04/03/mui-jelaskan-tentang-tiga-kali-tidak-shalat-jumat-saatpandemi/?_t=j2uL2QBMViWoPj5yM4e8vKUijt9aHJifv55ZAbG9s6rUPa2wOCoUiPrifZ7m cvNv\#.

23 Ibid.

24 Prayer.

25 Ablution (wudhu is usually done before prayer which requires the cleanliness and purity).

26 Putu Merta Surya Putra, "Wapres Minta Mur Keluarkan Fatwa Boleh Salat Tanpa Wudu Bagi Petugas Medis Covid-19," Liputan6.Com, March 23, 2020, https://www.liputan6.com/ news/read/420922o/wapres-minta-mui-keluarkan-fatwa-boleh-salat-tanpa-wudu-bagi -petugas-medis-covid-19.

27 "Fatwa MUI Tentang Pedoman Kaifiat Shalat Bagi Tenaga Kesehatan Yang Memakai Alat Pelindung Diri (APD) Saat Merawat Dan Menangani Pasien covid-19," Pub. L. No. 17, $1(2020)$.
} 
Islam regulates the way to handle dead bodies according to the guidance of the Sharia law. ${ }^{28}$ On March 27,2020 , the MUI issued fatwa $\# 18$ of 2020, concerning Guidelines for Handling Muslim's Dead Bodies (Tajhiz Al-Jana'iz) infected by CoviD-19. The fatwa states that the rights of the body must be observed, namely, it must be bathed, shrouded, prayed over, and buried, all of which must be carried out in a way that ensures the workers' safety by complying with the provisions of the medical protocols. ${ }^{29}$

\subsection{Protestant Responses}

Protestantism in Indonesia comprises various streams, including Lutheran, Calvinist (Reformed, Presbyterian), Anglican, Mennonite, Baptist, Methodist, Adventist, Pentecostal, and Charismatic groups. ${ }^{30}$ The diversity of the Protestants in Indonesia has resulted in different responses to the CoviD-19 epidemic. On March 15, 2020, PGI, which is the largest organization of churches in Indonesia, appealed to Protestants to attend services online (e-church). Churches that still conducted worship on March 15, 2020, were encouraged to provide handwashing facilities, body temperature gauges at the entrance, and to disinfect the place of worship before the service. ${ }^{31}$ On March 16, 2020, the PGI issued a formal letter containing an appeal not to hold church services involving large numbers of people and to replace them using social media tools. ${ }^{32}$

The PGI appeal received a positive response from various church leaders, although some ignored it. On March 19, 2020, church leaders in Bandung belonging to 25 denominations and 11 Christian religious institutions attended by Christian leaders, and the Ministry of Religion of the West Java Province Office agreed to prevent COVID-19 transmission by limiting services for the next two weeks to the congregants' homes. ${ }^{33}$

28 Agus Riyadi, "Upaya Pemberdayaan Dan Peningkatan Keterampilan Pemulasaraan Jenazah Di Wilayah Kecamatan Mijen Kota Semarang," Dimas 13, no. 2 (2013), 202.

29 "Fatwa Tentang Pedoman Pengurusan Jenazah (Tajhiz Al-Jana’iz) Muslim Yang Terinfeksi Covid-19," Pub. L. No. 18, 1 (2020).

$30 \quad$ Jan S Aritonang, Berbagai Aliran Di Dalam Dan Di Sekitar Gereja (Jakarta: B Pк Gunung Mulia, 1995).

31 Devina Halim, "Untuk Cegah Virus Corona, PGI Imbau Kembangkan e-Church," Kompas. Com, March 15, 2020, https://nasional.kompas.com/read/2020/03/15/20222571/untuk -cegah-virus-corona-pgi-imbau-kembangkan-e-church.

32 PGI, "Imbauan Majelis Pekerja Harian Persekutuan Gereja-Gereja Di Indonesia" (2020).

33 Bambang Widjaja, "Gereja-Gereja Di Kota Bandung Bersatu Menghadapi Wabah COVID-19 - YouTube," 2020, https://www.youtube.com/watch?v=EdrGgxjFpGo. 
The Christian Church of Indonesia (GKI ${ }^{34}$ ) Region Synod of West Java canceled assembly for the purpose of worship starting on March 22, 2020 ${ }^{35} \mathrm{On}$ March 14, 2020, the Jawi Wetan Christian Church (G KJW ${ }^{36}$ ) issued pastoral letter $14 / \mathrm{GS} / 03 / 2020$ about the coronavirus, stating that the congregation must pay attention to the prevention of COVID-19 by following health protocols that have been recommended by the government. ${ }^{37}$ On March 16, 2020, the GKJW issued letter $168 / \mathrm{vi} / 3 / 2020$ that called on congregants to conduct all activities of the community service (Sunday Service/Patuwen/Family), to the extent possible, at home with the families. ${ }^{38}$ Nevertheless, the letter mentioned that those who wished to worship communally were required to observe the health protocols, as outlined in the PGI letter of March 15, 2020.39

The mainstream church group, which to the best knowledge of the author operates largely under the auspices of the PGI, did not conduct a theological debate about canceling Sunday services starting from March 22, 2020, and replacing them with online services. By contrast, in Pentecostal and Charismatic groups some church leaders objected to the appeal on various grounds. As a result, on March 22, 2020, some churches, such as the Pentecostal Church of Indonesia $\left(\mathrm{GPdI}^{40}\right)$ in Menganti, Surabaya, East Java, ${ }^{41}$ and the (GPdI) Maranatha on S. Parman Street, Medan, North Sumatra, still held services. ${ }^{42}$ Various groups criticized this act. ${ }^{43}$ Although on March 19, 2020, the GPdI Chairman of the Central Assembly issued an appeal to cancel worship involving a large

34 Gereja Kristen Indonesia.

35 GKI, "Pesan Pastoral BPMSW GKI SW Jabar Tentang Upaya Menanggulangi Penyebaran COVID-19 - SELISIP.Com," accessed April 28, 2020, https://selisip.com/2020/03/ pesan-pastoral-bpmsw-gki-sw-jabar-tentang-upaya-menanggulangi-penyebarancovidig/.

36 Gereja Kristen Jawi Wetan.

37 PHмA, "Nomor: 14/GS/03/2020 Surat Penggembalaan GKJW Tentang Virus Corona," GKJW, March 14, 2020.

38 PнмA, "Nomor: 168/vi/3/2020 Surat Pemberitahuan Dan Himbauan," GKJW, March 16, 2020.

39 Ibid.

40 Gereja Pantekosta di Indonesia.

41 Audrey Santoso, "PGI Sesalkan Gereja Pantekosta Di Surabaya Abaikan Imbauan Social Distancing," DetikNews, March 23, 2020, https://news.detik.com/berita/d-4949402/pgi -sesalkan-gereja-pantekosta-di-surabaya-abaikan-imbauan-social-distancing.

42 Khairunas, "Ada Imbauan PGI, GPdI Maranatha Medan Tetap Ibadah Minggu Di Gereja Medan Metro - MedanBisnisDaily.Com," MedanBisnisDaily, March 22, 2020, http:// www.medanbisnisdaily.com/news/online/read/2020/03/22/103712/ada_imbauan _pgi_gpdi_maranatha_medantetap_ibadah_minggu_di_gereja/.

43 ARP, "Tetap Jalankan Ibadah Di Tengah Wabah Corona, GPdI Menganti, Surabaya Dikecam | MAJALAH SPEKTRUM," Majalah Spektrum, March 24, 2020, https://majalahspe ktrum.com/2020/03/24/tetap-jalankan-ibadah-di-tengah-wabah-corona-gpdi-menganti -surabaya-dikecam/. 
number of people, response to this appeal seems to have been weak. ${ }^{44}$ According to Ps. Ephraim Dacosta, GPdI Bethesda Makasar continued to hold Sunday services because it was inconceivable to hold Holy Communion online. ${ }^{45}$

On March 25, 2020, the Daily Workers Board of Indonesian Bethel Church $\left(\mathrm{GBI}^{46}\right)$, and Pentecostal and Charismatic churches that are members of the PGI issued circular letter $078 / \mathrm{S}-\mathrm{XVI} / \mathrm{SU} / \mathrm{BPH}-\mathrm{GBI} / \mathrm{III} / \mathbf{2 0 2 0}$. The main points of the letter were: (a) GBI local congregations must obey the central and regional government, and all worship activities are to be held online; (b) Good Friday and Easter service would be held online; and (c) Holy Communion was to be carried out independently, led by the pastor of the congregation by live streaming. In the absence of wine and bread, these could be replaced by tea and bread or cake. ${ }^{47}$

\subsection{Catholic Responses}

The Catholic response to the CoviD-19 pandemic tended to be in line with government recommendations, although a considerable number of mass gatherings continued to be held. On March 2, 2020, the Roman Catholic Archdiocese of Jakarta $\left(\mathrm{KAJ}^{48}\right)$ issued an appeal letter. At the time there was no indication that the KAJ was aware of a patient who had tested positive for COVID-19 in Indonesia. Appeal Letter 140/3.5.1.2/2020 stated that "[a]lthough it has been found in more than $5^{\circ}$ countries, not a single case of CoviD-19 has yet been found in Indonesia..." ${ }^{49}$ This means that the KAJ was aware of the importance of a serious response to the propagation of COVID-19 and its transmission, before any definite warning has been issued by Indonesian government authorities. After consulting with physicians from the Carolus Hospital and the KAJ Health Commission, KAJ issued an appeal letter addressed to all parishes in their working areas drawing attention to the possible spread of Covid-19. ${ }^{50}$ Worship was still held in the church, but those who were suffering from respiratory illnesses were advised to stay at home, and the congregation was advised

44 MPGPDI, "Himbauan Ketua Umum MP GPdI Tentang Kegiatan Ibadah Ditiadakan Sementara," MPGPDI, March 19, 2020.

45 "Gereja Bathesda Makassar Tetap Laksanakan Ibadah Minggu - YouTube," accessed April 28, 2020, https://www.youtube.com/watch?v=cDm15oEuX_E.

$46 \quad$ Gereja Bethel Indonesia.

47 BPHG BI, "Surat Edaran No. 078/S-XVI/SU/BPH-GBI/III/2020 Badan Pekerja Harian Gereja Bethel Indonesia," GBI, March 25, 2020.

48 Keuskupan Agung Jakarta.

49 Samuel Pangestu, "Surat Himbauan: Informasi Tentang Kewaspadaan Terhadap coviD-19 Untuk Umat Keuskupan Agung Jakarta," Keuskupan Agung Jakarta (Jakarta, March 2, 2020).

Ibid. 
to maintain physical distancing. ${ }^{51}$ On March 3, 2020, the Roman Catholic Archdiocese of Semarang $\left(\mathrm{KAS}^{52}\right)$ issued appeal letter 0257/A/X/2020-11, whose contents were almost identical with that of the KAJ letter. ${ }^{53}$

On March 15, 2020, after President Joko Widodo made an appeal to worship at home, several dioceses responded quickly. For example, on March 19, 2020, the Roman Catholic Archdiocese of Semarang (KAS) issued Bishop's Letter 0332/A/X/20-13 stating: "People's grief and anxiety are caused nowadays by the spread of the CoviD-19 coronavirus. This is also the source of our grief and anxiety, both of the pastors and people of the Roman Catholic Archdiocese of Semarang (cf. Gaudium et Spes art. 1)." Because of suspicion that the transmission of the CoviD-19 occurred partly as a result of encounters involving large numbers of people, KAS decided to prohibit all church activities involving many people for 15 days, from March 20 to April 3, 2020. ${ }^{54}$ The letter also included an invitation to "cooperate with a heightened sense of solidarity, care, and social responsibility." 55

Considering the fact that the COVID-19 pandemic did not end by the time of the Easter celebration, on March 23, 2020, KAS issued the letter 033/A/x/20-15 concerning the extension of the worship emergency period by suspending all church activities involving a large number of people until April 30, 2020, or until a new policy is in force. ${ }^{56}$ The Roman Catholic Archdiocese of Jakarta ${ }^{57}$ and The Roman Catholic Archdiocese of Bandung acted similarly.58

The Catholic Church in Java followed all government appeals, without any objections. But outside of Java, in Ruteng, Manggarai, NTT, an event was held on March 19, 2020 with the participation of around 1,500 people. This happened despite the appeal by Doni Monardo, the head of the Task Force for the Handling of Coronavirus, who asked the Diocese of Ruteng, Manggarai, NTT, to postpone the ordination of Mgr. Siprianus Hormat as Bishop of Ruteng. The Minister of Communication and Information (Menkominfo), Johny G. Plate,

$51 \quad$ Ibid.

$5^{2} \quad$ Keuskupan Agung Semarang.

53 Robertus Rubiyatmoko, "Surat Himbauan Pencegahan Penularan Dan Penyebaran Virus Corona," Keuskupan Agung Semarang (Semarang, March 3, 2020).

54 Robertus Rubiyatmoko, "SURAT GEMBALA Nomor : 0332/A/x/20-13 Surat Gembala Berkaitan Dengan Covid-19," Keuskupan Agung Semarang (Semarang, March 19, 2020). Ibid.

56 Robertus Rubiyatmoko, "Surat Nomor : 0338/A/x/20-15 Tentang Surat Edaran Perpanjangan Masa Darurat Peribadatan," Keuskupan Agung Semarang (Semarang, March 23, 2020).

57 Samuel Pangestu, "Surat Keputusan," Keuskupan Agung Jakarta (Jakarta, March 19, 2020).

$5^{8}$ Antonius Subianto Bunjamin, "Keuskupan Bandung - Blog Post," Keuskupan Agung Bandung (Bandung, March 20, 2020), http://www.keuskupanbandung.org/blog/post/ tenanglah-aku-ini-jangan-takut. 
a native of Ruteng, refused to attend the ceremony for no apparent reason. This event was held because it had been planned several months earlier. Manggarai regent, Deno Kamelus, argued that the event was held under tight health screening, with organizers providing hand sanitizers and checking the body temperature of churchgoers before they entered the premises, and claimed that they followed the protocols of the central government. ${ }^{59}$ Although the event was considered to violate the appeal of the government, given the nature of that appeal, no legal sanctions were imposed.

Because of the strong organization of the Catholic Church, its response was almost the same in each diocese. For example, the Palembang Archdiocese issued an 11-point circular relating to CoviD-19;60 on March 19, the Samarinda Archdiocese also announced that they would cancel routine weekly services for the next two weeks; ${ }^{61}$ and the Medan Archdiocese acted similarly. ${ }^{62}$

\section{3}

\section{Conclusions}

The response of religious communities to government policies in Indonesia varied. Islam, as a religion governed by Sharia law, required the MUI to issue a fatwa containing the prohibition against holding worship meetings involving many people. A small group of extremist Muslims initially opposed the policy, but eventually fell in line with it. Among Protestants, the mainstream churches, as well as the Pentecostal churches under the PGI, acted according to government regulations. Some Pentecostal churches tried to continue holding communal worship for the purpose of communion, but eventually followed government regulations. The Catholic church followed government regulations consistently, adopting a policy for dealing with the CoviD-19 pandemic.

59 Markus Makur, "Hundreds Attend Ordination Mass in East Nusa Tenggara despite COVID-19 Warnings," TheJakartaPost, March 19, 2020, https://www.thejakartapost.com/ news/2020/03/19/hundreds-attend-ordination-mass-in-east-nusa-tenggara-despitecovid-19-warnings.html.

6o Tribun Sumsel, "Keuskupan Agung Palembang Keluarkan 11 Point Edaran Terkait COviD-19," Tribun Sumsel, March 20, 2020, https://sumsel.tribunnews.com/2020/03/20/ keuskupan-agung-palembang-keluarkan-11-point-edaran-terkait-covid-19?page=all.

61 Fathur, "Keuskupan Agung Samarinda Tiadakan Misa Demi Pencegahan Corona," 2020, https://selasar.co/read/2020/03/19/1108/keuskupan-agung-samarinda-tiadakan-misa -demi-pencegahan-corona.

62 Nat, "Cegah Covid-19, Keuskupan Agung Medan Tiadakan Misa Di Gereja - Tribun Medan," Tribun Medan, March 20, 2020, https://medan.tribunnews.com/2020/03/20/cegah -covid-19-keuskupan-agung-medan-tiadakan-misa-di-gereja. 